\title{
Embracement as an analyzer of the relationships between professionals, managers and users*
}

\author{
O acolhimento como analisador das relações entre os profissionais, gestores e usuários \\ La acogida como analizador de las relaciones entre los profesionales, gestores y usuarios
}

Cinira Magali Fortuna ${ }^{1}$, Karemme Ferreira de Oliveira² ${ }^{2}$ Adriana Barbieri Feliciano ${ }^{3}$, Mônica Vilchez da Silva ${ }^{4}$, Flávio Adriano Borges², Gabriela Alvarez Camacho ${ }^{4}$, Priscila Norié de Araujo², Márcia Niituma Ogata ${ }^{3}$

How to cite this article:

Fortuna CM, Oliveira KF, Feliciano AB, Silva MV, Borges FA, Camacho GA, et al. Embracement as an analyzer of the relationships between professionals, managers and users. Rev Esc Enferm USP. 2017;51:e03258. DOI: http://dx.doi.org/10.1590/S1980-220X2016003303258

* Extracted from the thesis " Práticas de acolhimento e os modos de gestão na atenção básica em saúde à luz da análise institucional", Departamento de Enfermagem Materno-Infantil e Saúde Pública, Escola de Enfermagem de Ribeirão Preto, Universidade de São Paulo, 2015.

${ }^{1}$ Universidade de São Paulo, Escola de Enfermagem de Ribeirão Preto, Departamento Materno Infantil e Saúde Pública, Ribeirão Preto, SP, Brazil

${ }^{2}$ Universidade de São Paulo, Escola de Enfermagem de Ribeirão Preto, Programa de Pós-Graduação em Enfermagem em Saúde Pública, Ribeirão Preto, SP, Brazil.

${ }^{3}$ Universidade Federal de São Carlos, Programa de Pós-Graduação em Gestão da Clínica, São Carlos, SP, Brazil.

${ }^{4}$ Universidade Federal de São Carlos, Programa de Pós-Graduação em Enfermagem, São Carlos, SP, Brazil.

\section{ABSTRACT}

Objective: Analyzing the relationships among professionals and between professionals with managers and users based on the user embracement analyzer. Method: A qualitative study incorporating the theoretical-methodological reference of institutional analysis. The data were produced through focus groups and organized from transcription, transposition and reconstitution. Seventeen (17) focus group sessions were conducted involving six municipalities and health professionals from various backgrounds. Results: 137 professionals participated in this study. User embracement has been carried out with the aim to organize spontaneous demand. Doctors have not been directly involved, although they have the final say. Intermediate nursing deals with the users and nurses perform important negotiation work among the network sectors. The receptionists and the community agents develop the first approach to the users, forwarding them to nursing to negotiate the service. Managers hope to avoid complaints by attending everyone. Users take advantage of party politics and of the media for services when there is no access. Conclusion: User embracement is an analyzer, since it produces visibility and readability of the relations being produced in health services, and when analyzed can lead to denaturalizing these actions.

\section{DESCRIPTORS}

User Embracement; Primary Health Care; Interprofessional Relations; Primary Care Nursing.
Corresponding author:

Cinira Magali Fortuna

Av. Bandeirantes, 3900 - Campus Universitário

CEP 14042-902 - Ribeirão Preto, SP, Brazil

fortuna@eerp.usp.br
Received: 02/19/2016

Approved: 05/05/2017 


\section{INTRODUCTION}

According to a French sociologist, nowadays in the world a series of occupations and professions are constituted by relations ${ }^{(1)}$. These occupations have human beings as their object, unlike others whose objects are, for example, an engine (the mechanic), symbols (the mathematician), or the land (the farmer). Health professions such as nursing and medicine (among others) are among relational occupations.

Relational professions have been growing in the present, yet at the same time the ways of relating are also changing. Such a society is known as "a society of relations", adding that title to those listed contemporaneously: society of knowledge, society of information, society of service ${ }^{(1)}$.

In Brazil, collective health authors ${ }^{(2-4)}$ state that health is an occupation which is set up in the socio-historical context. These authors consider that health outcomes are immaterial goods, a symbolic good produced from the relation between the worker and the user through reading needs and using instruments (including knowledge), aiming at the transformation of something previous into something new/different, in order to accomplish an end goal.

It can be said that health workis relational,complex and that it updates economic, political and sociohistorical disputes ${ }^{(3)}$.In these relations, immaterial and symbolic goods are produced (since health has distinct and unique meanings, meanings experienced and produced by each person in sync with their context and culture). Such relationships also produce health workers, managers, care recipients, in a certain way producing two-way manufacturing: a factory that manufactures.

This factory that manufactures and is manufactured is the health institution, whose health services are updated by its organizations, for example, the Ministry of Health, the State and Municipal Health Secretariats, their establishments (health units) and equipment (appliances, instruments). Institutions are logical and their ways of operating are not always explicit; this arrangement composes the society and dictates its functioning, its permissions, omissions and prohibitions ${ }^{(5)}$.

Each institution is overlapped by several others. For example, there is a technical and social division of labor in health that is also considered as an institution ${ }^{(5)}$, and they both interconnect.

Health norms and rules presuppose that an unhealthy individual seeks a service that is offered by professionals who have knowledge capable of restoring and/or interceding to avoid or delay death, pain and suffering. In this encounter, the person suffering and the health professional conduct a series of rites using certain objects and sequences to be followed. In this ritual, both are covered with the symbol of a given intervention on a given course of events. This course is the course of life in its journey towards death.

Health services are organizations and establishments where meetings between professionals/workers, and between users and professionals take place. There, care is organized according to the logic, rules and norms that have been carefully thought out, elaborated and instituted, whether or not they have been accepted by the labor agents or by society for their execution.
Institutions are dialectical compositions. Their most stable form consists of what has been instituted. Movements of instituted transformation are known as institutional forces; while the result of this interplay of forces corresponds to the process of institutionalization ${ }^{(5-6)}$.

In health, there is an established logic for seeking services. This search happens when a need or a lack of something is acknowledged, usually by identifying that something is not well. In Primary Health Care services (PHC) specifically, there is a logic that this search should take place before illness, as a preventive and planned manner. There is also the expectation that people, in adopting healthy lifestyles, are capable of taking care of themselves and become autonomous.

Thus, there are disagreements and contradictions that put a strain on health institutions, because there are different expectations and interpretations among professionals and users about when they should seek services and what is or is not a legitimate health need ${ }^{(3)}$.

The purpose of institutional analysis is to highlight the contradictions and the logic that materialize through workers' practices ${ }^{(5-6)}$. Instituted logic and contradictions those in progress and those being produced - are revealed through analyzers, meaning facts, events, speeches etc. that express the tensions and power relations that make up a given phenomenon ${ }^{(7)}$.

In Brazil, user embracement was proposed as a device to reorganize the work process in health services as a way of highlighting the ways that care and the lack thereof is being produced $^{(8-9)}$. It is one of the perspectives of the Unified Health System (SUS - Sistema Único de Saúde) National Humanization Policy (PNH) which defines it as a process that permeates all consultations, a listening approach that takes into account the health needs of the users and goes beyond the biological and immediatist vision ${ }^{(10)}$.

The authors of this research have been working for some years in the scope of municipalities that are linked to a Regional Health Department of the interior of São Paulo through the modality of research interventions. In the experienced reflection spaces, the researchers formed a collective with the workers of these departments for the coproduction of data that are submitted to analysis, but that also translate into reflections on management practices and the care provided by health services at these places, aiming to qualify them. The daily life of these municipalities has shown that there are numerous challenges to be faced, and user embracement in these services is a practice that deserves reflection. This study sought to shed light on some of these issues.

Although several studies ${ }^{(8-11)}$ have been produced on user embracement, no publication dealing with an analyzer focusing on the present logic, the relations and $\mathrm{PHC}$ practices among health services was found, thereby justifying this research. Moreover, despite that the practice of user embracement should be exercised by all professionals who compose the staff of a health establishment, the leading role of the nursing team as the 'front line' for welcoming users at all health care levels is notorious. Thus, understanding it as an analyzer may indicate clues which are capable of 
problematizing the relationships between nurses and several professionals, and of these with health service managers and users; therefore, the question that guides this work emerges as: What does user embracement as an analyzer reveal about the relations between professionals and between professionals with managers and users?

Therefore, based on the health professionals' perspective, this study aims to analyze the relationships established between professionals, and between professionals, managers and users through the user embracement analyzer.

\section{METHOD}

This study is part of a research financed by the partnership between the National Council for Scientific and Technological Development (CNPq - Conselho Nacional de Desenvolvimento Cientifico e Tecnológico), the Ministry of Health, the São Paulo Research Foundation (FAPESP Fundação de Amparo à Pesquisa do Estado de São Paulo) - in the SUS Research (PPSUS) modality - and the São Paulo State Department of Health (SES/SP). The study was developed in the six municipalities that comprise the Heart Health Region of the Regional Health Department of Araraquara (DRSIII) of the SES/SP. These municipalities have some characteristics that bring them closer such as organization of user embracement to the population in health facilities, and others that distance them, especially regarding demographic indexes and the quantity of services offered.

This is a qualitative research implementing the theoretical-methodological reference of institutional analysis ${ }^{(5)}$. The study was approved by the Human Research Ethics Committee of the Escola de Enfermagem de Ribeirão Preto of the Universidade de São Paulo (CAAE Protocol Number 35014514.5.0000.5393) and followed the outlined recommendations for this type of research such as prior clarification, signing of the Free and Informed Consent Form with receipt of a signed copy, secrecy, confidentiality and nonidentification of the subjects who participated in the study.

Data were produced through focus groups conducted from December 2014 to April 2015. Group interviews (another name also attributed to focus group) can produce rich data that is produced from the interaction. This technique has been used in both quantitative and qualitative studies, and it is commonly understood as a group focusing on a subject led by a researcher. In this study, however, a different focus group perspective was adopted in which the research coordinator was not the one who rigidly directs a conversation with several people. Instead, their role was to stimulate conversation about a theme, considering the differences of power and knowledge between the participants, and also betting that the complexity of the themes can be better explored within these differences ${ }^{(12)}$.

The group's apparent daydreaming or going off topic are also aspects to be considered for understanding how that group behaves in being asked to discuss the theme, with the coordinator's role being to pay attention to what is said, the silences, the pauses, the nervous laughter, phrases spoken at the same time (which can demonstrate increased anxiety about an idea), provocations, among other aspects ${ }^{(13)}$.
In this format, we consider that the focus group has the objective of developing a collective production in the 'hereand-now' in an interwoven network that is made without the possibility to predict a priori its outcome, and that the coordinator has the role of mediating. In this study, user embracement was used as the axis of discussion and acted from the perspective of an analyzer, bringing up implicit and explicit issues experienced in the work routine by the health professionals involved. In this context, other issues also emerged from the strangeness of the information that was being brought up, and above all confronted and debated by the participants.

In order to put the groups together, managers of the indicated municipalities from each health unit were requested to indicate one worker with university education and another two with basic or medium level education. Each team voluntarily indicated these workers, who then attended the session on the day and at the place previously scheduled. The number of participants varied between 6 and 13 workers at each session. This design aimed to favor a greater number of workers with elementary/middle level education, thus enabling (in theory) reports from these professional categories in the groups. Inclusion criterion was being part of the health teams adhering to the Improvement Program of Access and Quality of Basic Care (PMAQ-AB). Exclusion criteria were being on vacation/leave due to sickness or any other reason during the period the research was carried out.

Each of the 137 participants belonged to one of the six municipalities of the Heart Health Region of DRS III and were identified according to their profession: psychologist, physician, dentist, oral health assistant, receptionist (clerk or administrative agent), nursing technician, nurse, nursing assistant or Community Health Agent (CHA). The sessions had an average duration of 90 minutes with two researchers participating: one in the role of silent observer and the other as group coordinator. The discussions started with guiding questions such as: Tell me how the work is organized in the Health Unit; Talk about user embracement in your Health Unit; among others.

In line with the adopted theoretical framework, data analysis was carried out throughout the research process which included preparing the researchers in workshops, developing the focus groups and writing this text. Data organization for analysis was performed based on three moments of the analysis process: transcription, transposition and reconstitution ${ }^{(14)}$.

For the transcription work, the audio recordings were converted into text files in Word format, which was performed by a contracted company paid with funds from the development agency that funded this study.

The transcribed texts were revisited by the researchers where technical terms and acronyms used in health or other inaccuracies were corrected. This review also aimed to highlight moments of tensions, dilemmas and overlapping speech.

The participants' speeches are not identified, except for some moments when they identified their professional category in being relevant to the analysis, and the focus group 
coordinator's speeches are also identified. Each group was named according to the sequence in which they occurred and its respective municipality, for example: FG1 Mun 1, FG2 Mun 1.

For transposition, all transcriptions were read several times in an attempt to find similarities and differences, questioning each group's line of discourse. During the course of the research, each focus group performed raised questions for the researchers which could be explored in the following groups.

The transposition was carried out through cutting out fragments that resonated with the objectives and with the theoretical reference during the reading. They were then also ordered during this process.

The authors carried out the transposition of the empirical material gathered in workshops for analysis, discussing the ordering of the fragments from different groups with the objectives guided by the institutional analysis framework, and thus constituting the results.

For didactic purposes, we can say that there is a moment of greater intensity of the data analysis in studies that use institutional analysis as a theoretical-methodological reference, which consists of the moment of institutionalizing the analysis through writing the results. Here we may draw a parallel with the moment of reconstitution proposed by authors linked to the qualitative methodolog $y^{(14)}$.

In this investigation, the analysis intensified when the final research reports were being developed. Tables and diagrams were produced in the analysis workshops based on the adopted framework. Thus, it was verified that user embracement presented itself as an analyzer of relations. Subsequently, it was collectively decided which aspects could be presented in the results.

The reconstitution process, although situated more strongly in the discussion of results, is also a moment of revisiting bibliographical references and going back to other productions for writing the final work. The main concepts regarding institutional analysis were revisited during the reconstitution, seeking to articulate them with user embracement issues in $\mathrm{PHC}$.

\section{RESULTS}

137 professionals participated in the study, where about $90 \%$ were female in the age group between 27 and 59 years, most were CHA, followed by nurses, nursing assistants and nursing technicians. Most of them only had one job. Professional experience time in primary care ranged from 2 to 24 years, and about $25 \%$ of university-level participants had a specialization in family health.

In all the involved municipalities, user embracement was discussed by workers mostly as a synonym of an initial service to users, especially for those who did not have appointments for medical consultations.

In general, the user arrives at the units' reception where they find the CHA or the receptionist. One of the groups referred to this meeting as triage and pre-user embracement, meaning that it is what precedes actual user embracement and is performed by the CHA, rather than the actual user embracement which is carried out by nursing assistants or nurses:

Our unit is more or less like that too, the person arrives, they are welcomed by the community health agent, who plays the reception part. Right there we are already performing, a pre-user embracement, in quotation marks. We talk to them and ask what is happening, they say something, and from that moment on we direct them to the user embracement with the nursing assistants or with the nurses (FG2 Mun 1).

Through the work of nurses or nursing technicians and assistants, the nursing sector is a mandatory path for users who do not have an appointment:

FG coordinator: Does every patient who comes in with spontaneous demand go through the nurse? FG participant: They go through Nursing. They usually do, we have the consultation right away in the morning, or the doctor arrives a little later... because the patients start arriving at 7 in the morning. So we don't even wait, we do the auscultation and we forward them... We ask the patients to go back home, so they don't have to wait there until the doctor comes back, and then we forward them to the consultation (FG1 Mun 2).

In one of the groups an interesting moment of discussion arose regarding a certain strategy that workers use to enable access to users that come in without a scheduled appointment: the "hidden appointment".

Nurse: But then, what do I do? I have a hidden appointment. FG Coordinator: What's that? Nurse: Some days, because there are enough doctors, I don't schedule anything. So at that time I do this user embracement, those (patients) I can schedule for another day, it's an allergy, or something like that, I have this bidden appointment that I can schedule for tomorrow or for the day after tomorrow, understand? FG coordinator: You say it's a bidden appointment because the doctor doesn't know about it? (Several people speaking at the same time) (FG1 Mun 3).

Although they do not participate directly in the user embracement, physicians end up defining the cases that will be attended based on reading what the other professionals have written:

When the user embracement is done by the nursing assistants, if the patient has a need for urgency, they are attended, or they are released by the doctor. If they came in for scheduling an appointment, then we will write it down in the medical record and the doctor evaluates the need for that patient's priority (FG5 Mun 1).

Even in larger municipalities there is political-party interference for requesting consultations, even when the workers have defined that the service could be performed at another time. Thus, users' strategies for getting an appointment when they deem necessary are expressed, such as appealing to political-party issues and threatening exposure through the press.

So they (users) seek other means, and they also think that we are unwilling. Then they come in like, "I told you so." Today, we were even discussing this, "There, I got it, see?" This change of professionals in the network, then, we do not have any reference (any backup). They threaten us sometimes. Saying, "I'm going to get the EPTV" (local television network), I think it's absurd to tell us over the phone that they'll call EPTV (FG3 Mun 1). 
The problem is that there are also a lot of clients. Because, so, sometimes, you had to do something and then they don't like us, so they go to the city hall to complain, and often you have to go back and figure out, "Oh, why didn't you attend that patient, why wasn't helshe attended? I'm sending him/her back there again to be seen." (FG5 Mun 1).

Dealing with spontaneous demand interweaves relations of "demand" from nursing with the doctors, and difficulties are experienced as a result of individual characteristics. Sometimes this partnership happens, sometimes they create a difficulty from the point of view of nursing, who has their own perspective on what could be attended. The "fixed places" of one and the other are produced, such as: good doctors are the ones that fit patients in, good nurses are the ones who solve the case/problem:

There are two scheduled appointments, but when you arrive, if you talk to him ... he is a good person, but he is on vacation (FG1 Mun 2).

Where we work the doctor is in the Center (name) all day long. So we usually talk to her. And she says, "Oh no, you're going to have to forward it" (FG2 Mun 2).

Faced with the spontaneous demand, flexible medical hours and daily contact with users who arrive at the service requesting medical consultations, nurses consider taking on and prescribing, for example, cases of arterial hypertension (HT) and diabetes mellitus (DM) through protocols, which is not possible:

The doctor is not at the unit all the time. My doctor arrives at 9 am and leaves at 11am. Then he comes back at 02:00 p.m. and leaves at 04 p.m. And then... we the nurses, we don't have the autonomy to prescribe medication. We may be doing the user embracement and guiding the patient, but regarding the prescription we don't have that support to do it. So in these cases, if it is an urgent case, we will refer them to the hospital, where there is a doctor 24/7. You understood? So, our reality is a bit difficult in that way. We don't have the autonomy to give prescriptions. Maybe ... for chronic diseases, for example, I'll mention one example, hypertension and diabetes, perhaps the municipality could create a care protocol for nurses to have the work autonomy (FG2 Mun 2).

When the person comes and asks to go through a routine consultation, exams are required, and if the results came back normal, there is no need for a return appointment. The nurse looks at the results, talks to them, and tries to avoid scheduling new medical appointment. There is follow-up organization also ordered by the results, which when altered, then schedules and appointments are made. There are references that when it is the nurse who talks to the patient, they indicate that there is no need for another consultation, so there is less "confusion":

(...)Because the (results from) examinations they are altered, they warn us, the nurse asks us to call the patient and schedule an appointment. With the exams that are not altered, they send us and the person goes there to see it and schedule the consultation afterwards. Another thing that has changed a lot is that there are always those stressed out (patients) who want to be seen that day, but it's not an emergency. And our nurse, she is a lovely person, she talks with them gently, so people do not argue there anymore. There isn't arguing anymore. We say, "No, today it's not possible, would you like to talk to the nurse?", and then she (nurse's name) talks to them, explains why it's impossible, the person understands and ends up leaving. So, there is no more complaining at our clinic (FG2 Mun 2).

Nurses begin to take on care directly, offering other actions to meet the demand for medical consultations:

The mentality is that they think the doctor was, and for some still is, the "father of all", that the unit only works because there is a doctor, and we can prove it otherwise. We can ask for a blood count, ask for a pregnancy test, look at how much time that saved the doctor. We do the check-ups, we can do it (FG3 Mun 4).

Another aspect present in most municipalities is the lack of adequate structure, both in terms of materials (equipment, rooms) and networking, as well as an inadequate number of workers, thus comprising a disintegrated care network.

Now there's a new manager. Last month I got a patient an appointment with the Neurologist (in São Paulo) and they left the patient here from three in the morning until the time I arrived at the clinic. There are many flaws. So, I think the infrastructure problem we managed to organize. But our infrastructure is still lacking. From whom? From the management team. We don't have any support, we don't have any backing. And often we ... it is not that we are discouraged, we are very supportive. The patient gets there and they don't care about anything, they just say, "Why don't they close this down? This place serves no purpose! (...) (FG1 Mun 4).

The day he went to our unit, our boss was on vacation, he said that he would like the service to be humanized and that he wanted the patients to feel comfortable, because they were already fragile, this is a reality that we understand, we know. But in face of all this, we suggested the opposite problem, the problem of people liking the service or the employees' care so much, even knowing that there isn't enough equipment and everything, that they came in bunches looking for this unit, even being from other neighborboods. (...) FG coordinator: You're saying that the users are heard, but that the health professionals don't? Part: Yes, yes, sometimes this is the case. Then people demand from us people actions/conducts that cannot happen, regardless of what is happening (FG2 Mun 4).

\section{DISCUSSION}

Although user embracement was proposed as a device to change the technical-assistance model, the data show that it is strongly related to screening actions and forwarding referrals. It is possible to identify a process of technification of what should be carried out through contact/interaction, listening and establishing pacts, meeting users' expectations. Instead, what is often noticed are 'pre-fabricated' responses and modulated listening to the complaint. This fact is related to historical and institutional issues of professional practices in health, in the sense of attending and having to solve, and to understand the resolution as a process of simplifying complex aspects and categorizing the population (diabetics, hypertensives, those with multiple complaints, etc.). 
For institutional analysis, professional practices occupy institutions and update them, and this is the reason for the interest in them. Institutional dynamics cross and permeate professional practices, and at the same time, the institution gains materiality in these practices $^{(6)}$.

User embracement highlights relationship modes in PHC settings in their logic, becoming an analyzer, and characterized as revealing what was not seen, or not said in the institution. Through user embracement, it was possible to identify the ways in which nurses, nursing technicians and assistants, physicians and CHA interrelate, and how all of them relate with users and municipal management.

Professions are updated and created in establishments and organizations ${ }^{(6)}$. The initial prophecy is a certain covenant promise that inaugurates the institutions and tends not to be fulfilled ${ }^{(5)}$, causing the institution to perpetuate. In the case of nursing, the prophecy that founds its modern professionalization is the promise of combating avoidable deaths through appropriate hygiene measures, a care based on technical and scientific principles recognized by the "academic" community, and the promise to end charitable, lay practices related to magic-religious vision about the healthdisease process, a requirement of positivist science.

Another trademark of the modern nursing institution's foundation is opposition to the medical profession, seeking autonomy in relation to it. In updating the foundation's trademarks in professional nursing practices developed in health organizations, especially in Basic Care $(A B)$ establishments, nurses seek autonomy, exerting a reference role for the team regarding user embracement, developing practices that increase access and proposing protocol activities that can optimize medical work, producing greater access. The claim for protocols to medicate and request tests falls within this inclusive perspective.

One study ${ }^{(15)}$ points to the multifunctionality of nurses' work in the Family Health Strategy (FHS) and weaknesses regarding its resoluteness and user embracement, findings that corroborate those of this research.

Another aspect to be identified regarding nurses' professional practices, and which user embracement highlights, consists of the relations established with the doctors. Tense relationships which result in the need to "ask" for a service favor for a user or establish strategies such as the "hidden appointment".

We also point out the fact that nurses' work regarding user embracement plays the role of reducing the volume of medical work. This fact evidences two professional institutions that are always at friction and crossing each other. On the one side there is nursing, which seems to seek recognition and autonomy through care activities that user embracement provides; and on the other the medical practice, which moves away from the apparently more arduous work of dealing directly with the clientele. In both, professional practices are divided by the technical institution and social division of labor ${ }^{(5)}$, with conflicting arguments.

Conflicts can represent different interests and sometimes they are a consequence of unequal distribution of resources, power relations and issues related to a profession that has a predominance of females and submission in its history. Devices that contribute to resolving these conflicts consist of team meetings, valorizing interprofessional work and strengthening intra-team-communication processes ${ }^{(16-17)}$.

For nursing, several relevant themes come up when discussing user embracement such as those related to PNH, education in health and education and training of other workers, which are articulated by proposals of putting themselves in other people's shoes, empathy, care and promotion of self-care. It is not by chance that in a review of the literature ${ }^{(11)}$ were found a considerable number of publications on user embracement performed by nurses and published in nursing journals.

Another study ${ }^{(18)}$ points out user embracement in the direction of empathy and education, something highly valued by nursing and which composes a certain institution of this professional practice.

For nursing technicians and assistants on the discussion about the user embracement, they describe their practice as a collaboration with nurses, mediating with doctors and other workers when nurses cannot.

Medical practices are still central in the organization of basic health units and in the production of what is constituted as a "heath need" in a more hegemonic way in capitalist society: diagnosis, prescription, medication and cure of the installed disease ${ }^{(19)}$.

As a more scarce resource, user embracement would perform a triage of those who will have access to medical practices. The others, in order not to be barred, must wait in an ordered queue to schedule an appointment for the day and time of their consultation.

Doctors see a specific number of people, and anything beyond that needs to be authorized by them. They stay only for a few hours in the units, even if the scheduled time is 4 hours and the estimated number is 16 consultations with a minimum duration of 15 minutes each. It is noted that they generally attend all the scheduled consultations within 1 to 2 hours, and go work in another health establishment. So the 15 minutes that seem so fast and insufficient for a proper consultation turn into much less. Regarding spontaneous demand and user embracement, the physicians participation is in authorizing (or not) inclusion of the patient, based on the speech or writing of other workers. This dialogue is permeated by tension and the doctor has the final word.

CHA are workers whose official tasks are to carry out family registration and update monthly visits (at least) to each of the 150 families under their care. Health promotion actions such as crafts, hiking, walking and parties are also included.

From the discussions about user embracement, it was possible to show that the CHA's work is directly related to nursing work, although basic care guidelines place these workers under the supervision of the FHS physician, nurse, and dentist. In some cities of the studied region, CHA workers have also occupied reception. In doing so, they leave the streets and home visits to enter into the unit, where they are more physically close to the professionals, but in a position of little value. On the other hand, in the reception of the unit they assume some power. 
In this sense, the bet that this CHA can bring users and health services closer, being the voice and bond of the population is not fulfilled, and the institution is showing strength in absorbing it, bringing them into the hegemonic scientific and Cartesian logic of the workers.

There are conflicting expectations in the relations of the health team with the municipal managers. Workers expect to be heard and supported by management, while they expect users not to complain, at times assuming positions that deempower the health team in their decisions regarding the moment of care and the needs. This aspect reinforces the polarizing relationship between health team and users.

A study ${ }^{(20)}$ on the attributes of primary health care demonstrates the non-correspondence between professionals' conception and those of the users in relation to issues involving this level of health care, evidencing the existing disagreements.

The strategy encountered by users is to complain to the press and to appeal to political-party issues, constituting a cycle that does not clearly discuss their rationalization of the medical resource, the fragmented health network, and health services as one more consumer good that should be available to all and at all times.

Another aspect that user embracement as an analyzer puts into visibility is the need to "talk" that often leads users to the health facility. This aspect is not considered legitimate by the workers. It is as if they are taking the place of people who "in fact" need care.

Relational professions, meaning professions which have as their purpose the "transformation of the other," including health, have dealt with a certain professionalization of life aspects, previously entrusted and exercised within the family, neighbor and friendship circles. When it was necessary to talk, these were the people they sought. Nowadays, these aspects have transitioned to the professional scope of specialists, depriving communities of this knowledge ${ }^{(1)}$.

\section{CONCLUSION}

Although user embracement was proposed in order to reorganize the work process and to recognize the population's legitimate health needs, the procedure performed by the professionals and assigned as user embracement is limited to the viability of spontaneous demand rather than one from scheduled medical consultations.

Professional nursing practices (nurses, technicians and nursing assistants), doctors, CHA and other health professionals are updated in basic health care services, producing the health institution in its logic. There is logic that updates the initial prophecy of professional practices, such as in the case of nurses seeking autonomy through proposing activities that increase access or that make users feel more confident that they can wait for medical care.

User embracement is a powerful analyzer of practices and relationships between professionals, management and users. It is believed that by being collectively analyzed, it can trigger a denaturalization of these practices and relations, opening possibilities for producing instituting processes that are capable of generating transformations in the health work process, and consequently in the health care provided to users.

\section{RESUMO}

Objetivo: Analisar as relações entre profissionais e destes com gestores e usuários a partir do analisador acolhimento. Método: Estudo qualitativo com referencial teórico-metodológico da análise institucional. Os dados foram produzidos por meio de grupos focais e organizados a partir da transcrição, transposição e reconstituição. Foram realizadas 17 sessões de grupos focais envolvendo seis municípios e profissionais de saúde de diversas formações. Resultados: Participaram da pesquisa 137 profissionais. O acolhimento vem sendo realizado na perspectiva de organizar o atendimento à demanda espontânea. Os médicos não têm se envolvido diretamente, embora detenham a palavra final. A enfermagem intermedia a lida com os usuários e exerce importante trabalho de negociação entre os setores da rede. Os recepcionistas e os agentes comunitários realizam a primeira abordagem aos usuários, dirigindo-se à enfermagem para a negociação do atendimento. Os gestores esperam evitar reclamações, atendendo a todos. Os usuários se valem da política partidária e da imprensa para atendimento quando não há acesso. Conclusão: $\mathrm{O}$ acolhimento é um analisador, pois produz visibilidade e dizibilidade às relações em produção nos serviços de saúde e ao ser posto em análise pode desencadear a desnaturalização destas.

\section{DESCRITORES}

Acolhimento; Atenção Primária à Saúde; Relações Interprofissionais; Enfermagem de Atenção Primária.

\section{RESUMEN}

Objetivo: Analizar las relaciones entre profesionales e de esos con gestores y usuarios mediante el analizador acogida. Método: Estudio cualitativo con marco de referencia teórico metodológico del análisis institucional. Los datos fueron producidos por medio de grupos focales y organizados mediante la transcripción, transposición y reconstitución. Fueron realizadas 17 sesiones de grupos focales involucrando a seis municipios y profesionales sanitarios de distintas formaciones. Resultados: Participaron en la investigación 137 profesionales. La acogida se está llevando a cabo en la perspectiva de organizar la atención a la demanda espontánea. Los médicos no se están involucrando directamente, aunque detengan la palabra final. La enfermería intermedia el manejo de los usuarios y ejerce importante trabajo de negociación entre los sectores de la red. Los recepcionistas y los agentes comunitarios realizan el primer abordaje a los usuarios, dirigiéndose a la enfermería para la negociación de la atención. Los gestores esperan evitar quejas, atendiendo a todos. Los usuarios se valen de la política partidaria y de la prensa para atención cuando no hay acceso. Conclusión: La acogida es un analizador, pues produce visibilidad y decibilidad a las relaciones en producción en los servicios sanitarios y, al ser puesta en análisis, puede desencadenar la desnaturalización de esas.

\section{DESCRIPTORES}

Acogimiento; Atención Primaria de Salud; Relaciones Interprofesionales; Enfermería de Atención Primaria. 


\section{REFERENCES}

1. Gonnin-Bolo A. Demailly Lise. Politiques de la relation. Approche sociologique des métiers et activités professionnelles relationnelles. Rev Fr Pédagogie. 2010; 171(1):150-1.

2. Carvalho BG, Peduzzi M, Mandú ENT, Ayres JRCM. Work and Inter-subjectivity: a theoretical reflection on its dialectics in the field of health and nursing. Rev Latino Am Enfermagem [Internet]. 2012 [cited 2016 Jan 25];20(1):19-26. Available from: http://www.scielo.br/ $\mathrm{pdf} / \mathrm{rlae} / \mathrm{v} 20 \mathrm{n} 1 / 04 . \mathrm{pdf}$

3. Merhy EE, Feuerwerker LCM, Silva E. Contribuciones metodológicas para estudiar la producción del cuidado en salud: aprendizajes a partir de una investigación sobre barreras y acceso en salud mental. Salud Colectiva [Internet]. 2012 [citado 2016 Jan. 24];8(1):25-34. Disponible en: http://www.scielo.org.ar/pdf/sc/v8n1/v8n1a03.pdf

4. Merhy EE. Multidão: esfinge da saúde pública, lugar de inflexão, ideias do bem comum. Saúde Soc [Internet]. 2015 [citado 2016 jan. 24];24 Supl 1:44-54.

5. Lourau R. L'analyse institutionnelle. Paris: Les Éditions de Minuit; 2003.

6. Monceau G. Entre pratique et institution. L'analyse institutionnelle des pratiques professionnelles. Nouv Rev Adapt Scolar. 2008;41(1):14559.

7. Zambenedetti G, Piccinini CA, Sales ALLF, Paulon SM, Silva RAN. Psicologia e análise institucional: contribuições para os processos formativos dos agentes comunitários de saúde. Psicol Ciênc Prof. 2014;34(3):690-703.

8. Franco TB, Bueno WS, Merhy EE. O acolhimento e os processos de trabalho em saúde: o caso Betim, Minas Gerais, Brasil. Cad Saúde Pública.1999;15(2):345-53.

9. Costa PCP, Garcia APRF, Toledo VP. Welcoming and nursing care: a phenomenological study. Texto Contexto Enferm [Internet]. 2016 [citado 2016 Ago 31];25(1):e4550015. Available from: http://www.scielo.br/pdf/tce/v25n1/0104-0707-tce-25-01-4550015.pdf

10. Barros MEB, Roza MMR, Guedes CR, Oliveira GN. O apoio institucional como dispositivo para a implantação do acolhimento nos serviços de saúde. Interface (Botucatu) [Internet]. 2014 [citado 2016 jan. 23];18 Supl1:1107-17. Disponível em: http://www.scielo.br/pdf/ icse/v18s1/1807-5762-icse-18-1-1107.pdf

11. Pelisoli C, Sacco AM, Barbosa ET, Pereira CO, Cecconello AM. Acolhimento em saúde: uma revisão sistemática em periódicos brasileiros. Estud Psicol. (Campinas) [Internet]. 2014 [citado 2016 jan. 23];31(2):225-35. Disponível em: http://www.scielo.br/pdf/estpsi/v31n2/ a08v31n2.pdf

12. L'Hostie M, Cody N, Laurin N. Caractéristiques et particularités du groupe de discussion favorisé dans un dispositif de recherche collaborative en éducation. Rech Qual. $2011 ; 29(3): 198-213$.

13. Leclerc C, Bourassa B, Picard F, Courcy F. Du groupe focalisé à la recherche collaborative: avantages, défis et strategies. Rech Qual. 2011;29(3):145-67.

14. Paillé P, Mucchielli A. L'analyse qualitative en sciences humaines et socials. 3ème éd. Paris: Armand Colin; 2012.

15. Silva SS, Assis MMA. Family health nursing care: weaknesses and strengths in the Unified Health System. Rev Esc Enferm USP [Internet]. 2015 [cited 2016 May 12];49(4):600-6. Available from: http://www.scielo.br/pdf/reeusp/v49n4/0080-6234-reeusp-49-04-0603.pdf

16. Oliveira AM, Lemes AM, Ávila BT, Machado CR, Ordones E, Miranda FS, et al. Relação entre enfermeiros e médicos do Hospital das Clínicas da Universidade Federal de Goiás: a perspectiva do profissional de enfermagem. Rev Latino Am Bioet. 2010;10(2):58-67.

17. Tabak N, Orit K. Relationship between how nurses resolve their conflicts with doctors their stress and job satisfaction. J Nurs Mang. 2007;15(3):321-31

18. Santos DA, Shirasaki RTS, Cangussu JML, Santos DA, Fermino JM, Silva AT, et al. Potencialidades e dificuldades nas práticas de acolhimento na rede de atenção básica conforme a Política Nacional de Humanização. Saúde Transf Soc. 2016;6(2):54-69.

19. Fertonani HP, Pires DEP, Biff D, Scherer MDA. Modelo assistencial em saúde: conceitos e desafios para a atenção básica brasileira. Ciênc Saúde Coletiva. 2015;20(6):1869-78.

20. Silva AS, Baitelo TC, Fracolli LA. Primary Health Care Evaluation: the view of clients and professionals about the Family Health Strategy. Rev Latino Am Enfermagem [Internet]. 2015 [cited 2016 May 12];23(5):979-87. Available from: http://www.scielo.br/pdf/rlae/v23n5/01041169-rlae-23-05-00979.pdf

Financial support:

Conselho Nacional de Desenvolvimento Científico e Tecnológico (CNPq). Process 306190/2014-1.

Ministério da Saúde. Fundação de Amparo à Pesquisa do Estado de São Paulo (FAPESP) and

Secretaria de Estado da Saúde de São Paulo. Process PPSUS 2014/50037-0. Coordenação de Aperfeiçoamento de Pessoal de Nível Superior (CAPES/PROEX). Doctoral fellowship. 